\title{
CURRENT STATE OF STUDENTS' HEALTH AND ITS IMPROVEMENT IN THE PROCESS OF PHYSICAL EDUCATION
}

D0I: 10.36740/WLek202007124

\author{
Grygoriy P. Griban', Natalia A. Lyakhova², Oleksii V. Tymoshenko³, Zhanna G. Domina³ , Nadya Yu. Dovgan4, \\ Mykola Z. Kruk', Ivan V. Mychka', Pavlo P. Tkachenko ${ }^{5}$, Bogdan S. Semeniv ${ }^{6}$, Ganna P. Grokhova ${ }^{7}$, \\ Natalya O. Zelenenk0 ${ }^{8}$, Kostiantyn V. Prontenko ${ }^{9}$ \\ 'ZHYTOMYR IVAN FRANKO STATE UNIVERSITY, ZHYTOMYR, UKRAINE \\ 2UKRAINIAN MEDICAL STOMATOLOGICAL ACADEMY, POLTAVA, UKRAINE \\ ${ }^{3}$ NATIONAL PEDAGOGICAL DRAGOMANOV UNIVERSITY, KYIV, UKRAINE \\ ${ }^{4} U$ UNIVERSITY OF THE STATE FISCAL SERVICE OF UKRAINE, IRPIN, UKRAINE \\ 5POLISSIA NATIONAL UNIVERSITY, ZHYTOMYR, UKRAINE \\ ${ }^{6}$ STEPAN GZHYTSKYI NATIONAL UNIVERSITY OF VETERINARY MEDICINE AND BIOTECHNOLOGIES LVIV, LVIV, UKRAINE \\ ${ }^{7}$ KHARKIV NATIONAL UNIVERSITY OF RADIO ELECTRONICS, KHARKIV, UKRAINE \\ ${ }^{8}$ NATIONAL UNIVERSITY OF PHARMACY, KHARKIV, UKRAINE \\ 95. P. KOROLIOV ZHYTOMYR MILITARY INSTITUTE, ZHYTOMYR, UKRAINE
}

\begin{abstract}
The aim is to investigate the state of health of the students of Ukrainian higher education institutions.

Materials and methods: The study of state of health was conducted at Polissia National University and Zhytomyr Ivan Franko State University in 2008-2019. The results of a medical examination of 3737 students of different faculties between the ages of 17 and 22 were examined. Medical examinations were conducted by the doctors of the medical centers of universities. Totally 1208 pupils (male and female) of the schools of Zhytomyr region were involved in the questionnaire, which was conducted to analyze the attendance of physical education classes by pupils while studying at school. 648 students of Polissia National University participated in the study of the self-assessment of their own health, causes, and structure of disease incidence, the dynamics of the loss of labor capacity.

Results: It was established that from 24 to $30.8 \%$ of the students had diseases and a low level of physical development that indicated a low level of physical education at schools. It was revealed that the number of sick students was increasing during the study at higher educational institutions (HEI) that led to missing classes. Besides, up to 35.5 $\%$ of students had health disorders and belonged to a special medical group. And $1.7 \%$ of the students had chronic diseases and disabilities and were exempted from sports. It was found that physical education and sports took the 5 th place in the system of life values of male students and the 12th place in the system of life values of female students. Conclusions: Physical education, aimed at enhancing the functional capacity of an organism, the development of physical qualities, the improvement of the special physical and technical readiness in the sphere of physical activity types and the acquisition of professionally applied skills and abilities, is the basis for strengthening the health of students of Ukraine.
\end{abstract}

KEY WORDS: health, diseases, physical education, students

Wiad Lek. 2020;73(7):1438-1447

\section{INTRODUCTION}

The problem of health has always been one of the most pressing problems both at the level of scientific cognition and at the level of everyday consciousness $[1,2,3]$. Considering the modern integrated interdisciplinary concept of health, it combines the psychological and physiological aspects of human health. The integral concept is not the only one among the theories of health, because health is studied by researchers in different scientific disciplines, including medicine, physiology, anatomy, psychology, ecology, pedagogy, and others $[4,5,6]$. Individual health is essential in the strategy and tactics of health promotion, preservation, and restoration, where individual, age, gender, constitutional, regional, and social health indicators are highlighted $[7,8]$.
Complete health is a rare condition for most people in general. However, young people, who are students, have higher resiliency, no discomfort, their mood and well-being are good, they are full of vigor and strength, and a careful examination can show no definite abnormality $[9,10]$. However, the majority of students usually do not have such vivid manifestations of health, well-being is a subjective characteristic $[8,11]$. Much of the scientists consider the term "health" as a condition of an organism that enables a person to implement the genetic program in the specific conditions of the socio-cultural existence of a human to the maximum extent $[12,13]$.

The concept of "health" of the population is characterized by a set of indicator, including demographic one (birth and 
deaths rates, average life expectancy), physical development (morphofunctional and biological development, harmony), disease incidence (general, infectious), disability (primary, general), the quality of donozological states (immunity, enzyme activity) $[14,15,16]$. The research [17] showed that the majority of freshmen (74.3\%) belonged to the main medical group, i.e. they were healthy. But $17.3 \%$ had various diseases, and $1.04 \%$ were exempted from sports, they had disabilities or were significantly sick. While studying at HEI, the number of students in the main group was reduced by $8.1 \%$, while the number of students in the special group was increased by $7.2 \%$. The number of students exempted from sports had been reduced by the 2 nd year of study and after that, there was a tendency of a slow increase in their number in the 3 rd year. Thyroid hyperplasia had been in the first position for three years among males. The second most prevalent group was digestive diseases, the third group included respiratory diseases [18]. The largest group consisted of acute respiratory diseases, including angina, influenza, chronic bronchitis, pneumonia, bronchial asthma. The number of diseases of the nervous system, sensory organs, and musculoskeletal system was increased. This resulted in an overall increase in disease incidents of the students by $9.6 \%$ [19].

According to research by E. Kotov [20], the majority of the 1st and 2nd-year students belonged to the main medical group. At the same time, 15-20\% of young people had health disabilities. The author noted that the number of students was constantly decreasing in the process of study in the main medical group, and increasing in the preparatory and special ones. From the first to the fourth year of study the number of students in the main medical group decreased by $22.5 \%$ among males and $17.5 \%$ among females.

The results of the research [21] showed that $37.2 \%$ of students of the 1 st -4 th years of study had a middle level of health indicators, $20.4 \%$ - lower than the middle, 13.2 $\%$ - low, $15.6 \%$ - higher than the middle, $12.0 \%$ - high. There was also an interconnection between somatic health and students' activity.

According to the Ukraine-wide monitoring of the Institute of Sociology NAS of Ukraine, $58 \%$ of young people (up to 30 years of age) stated that they were in good health, moreover, $36.4 \%$ of them rated their health as good and $47.9 \%$ - as satisfactory. Young people were mainly satisfied with their health and it was not a meaningful value for them [22].

As a result of annual medical examinations of the students from different HEI of Ukraine, it was found that $70-80 \%$ of freshmen had health disabilities $[14,15,23]$. Most of the diseases that made the students miss classes were cold-related diseases. There was also a direct correlation between an increase in the number of students who had a low level of physical fitness, and deterioration of somatic health, especially in endurance and speed tests $[12,21]$. Such motor qualities as general endurance, speed, agility, strength endurance, and flexibility are beyond the safe level of somatic health, indicating a direct correlation between health and physical fitness [24]. This peculiarity can be traced concerning almost all motor qualities, except upward jump and standing long jump that characterize such motor quality as speed force [25].

According to the research $[26,27,28]$, the level of physical health, which was calculated on the basis of indicators that have correlative relationships with maximum aerobic capacity and characterize the bioenergy of the body, was lower than the middle during the period of study. None of the students had a high level of health, and only $2-4 \%$ of students had higher than the middle level. The index of the physical condition during study decreased from the middle level of the 1st - 2nd grades to the lower than the middle in the $3 \mathrm{rd}-4$ th years of study. The authors also examined that $72 \%$ of the surveyed students had chronic diseases, the incidence rate was $112.5 \pm 6.2$ cases per 100 students (some students were determined to have 2-3 diseases), and the rate of the females was 1.4 times higher than the one of males. The diseases of the nervous system and sensory organs $(37.8 \pm 2.7 \%)$, the diseases of the endocrine system, eating disorders and metabolic disorders $(35.3 \pm 2.6 \%)$ took the leading places in the structure of the incident rate.

The scholars $[29,30]$ note that the level of students' health depends significantly on the state of physical education at school, following a healthy lifestyle by school pupils, and the prevention of diseases among pupils, that is, on the initial level of health of a HEI applicant. There has been a significant deterioration of health and a decrease in the level of fitness of young students in Ukraine for many years $[31,32]$. The examination of the physical development and physical fitness of the students of Polissya National University for thirty years showed that more than $50 \%$ of them could not pass physical tests with "satisfactory results". They had significant physical disabilities, diseases; from 10.9 to $20.5 \%$ belonged to the preparatory group, from 8.1 to $17.4 \%$ - to a special medical group, and from 0.4 to $1.2 \%$ were exempted from sports, had chronic diseases and disabilities [21].

The analysis of literary sources leads to the conclusion that health is determined as the interaction of many factors - social and biological, external and internal, material and spiritual, which interact with each other in a complicated and contradictory manner. Undoubtedly, health prevention is also significantly influenced by physical activity, i.e. physical education at schools and educational establishments. The quality of the educational process and the students' personally-oriented choice of physical activity depend on the health state of young people in Ukraine.

\section{THE AIM}

The aim of the study is to investigate the state of health of the students of higher educational institutions of Ukraine.

\section{MATERIALS AND METHODS}

The study of state of health was conducted at Polissia National University (PNU) and Zhytomyr Ivan Franko State University (ZSU) in 2008-2019. The results of a medical examination of 3737 students of different faculties be- 
tween the ages of 17 and 22, including 1929 students of PNU and 1808 students of ZSU, were examined. Medical examinations were conducted by the doctors of the medical centers of universities. Totally 1208 pupils (male and female) of the schools of Zhytomyr region were involved in the questionnaire, which was conducted to analyze the attendance of physical education classes by pupils while studying at school. 648 students of PNU participated in the study of the self-assessment of their own health, causes, and structure of disease incidence, the dynamics of the loss of labor capacity.

Research methods: theoretical (the analysis and synthesis of literary sources, the analysis of curricula, the assessment of the quality of classes with students of special medical groups, the study and analysis of medical cards of students); empirical (pedagogical observations, questionnaires, the methods of mathematical statistics).

This study complies with the ethical standards of the Act of Ukraine "On Higher Education" No.1556-VII dated 01.07.2014 and the Letter from the Ministry of Education and Science of Ukraine "On the Academic Plagiarism Prevention" No. 1/11-8681 dated 15.08.2018. Also, this study followed the regulations of the World Medical Association Declaration of Helsinki - ethical principles for medical research involving human subjects. Informed consent was received from all individuals who took part in this research.

\section{RESULTS}

The level of physical fitness and health of students while studying at HEI is significantly dependent on the physical condition of university applicants. The analysis of physical fitness, physical development and disease incidence of applicants showed that from 24 to $30.8 \%$ of them had diseases, including chronic, congenital anomalies, disability, very poor physical development (postural disorders, overweight or underweight, disproportionate physical development of the body, problems with the functionality of the body, etc.). Performing tests in physical education and assessing physical development, many students do not have technical skills or knowledge about the viability of such measurements and tests. This condition of the applicants' preparation substantially depends on the state of physical education classes and health-improving activities in Ukrainian schools. There are number of disadvantages of attending physical education scheduled and extracurricular classes at high school. There are some pupils from both rural and urban schools who did not attend physical education classes at all. We defined that $71.7 \%$ of males and $82.7 \%$ of females among the youth from rural areas and $47.1 \%$ of males and $75 \%$ of females among the youth from urban areas who did not attend any extracurricular activities in sections, sports schools, and clubs. And $50.7 \%$ of males and $75.6 \%$ of females from the rural area and $55.5 \%$ of males and $69.6 \%$ of females from the city did not do physical exercise themselves while studying at school (Table I).

This state of physical education at school will surely be reflected in the level of physical fitness and health of future students. The problem of students' health and physical fitness level arises by far earlier the entry of an applicant to HEI and requires a comprehensive and systematic solution within the country but not in a particular region or institution. In addition, the industrial and technical development of the industry caused significant changes in the environment, accelerated the rhythm and pace of life, computerization increased the nervous-emotional tension against the background of a significant decrease in motor activity, which contributed to the emergence of cardiovascular diseases, the diseases of the respiratory and musculoskeletal system, etc. Diseases are significantly reflected in the decline in students' performance and its complete loss. Our research during the calendar year, which included 648 students of PNU, showed that students lost $4.45 \%$ of school days out of the total number of days because of illness just in a year. The most common are cold-related diseases that make students lose their working capacity. The next are the diseases of musculoskeletal, respiratory, cardiovascular and nervous systems and others. The analysis of the causes of the loss of labor capacity by university students showed significant differences between males and females not only in the number of diseases but also in their consequences. Thus, $2.18 \%$ of first-year male students lost their working capacity during the year, the number of such female students accounted for $6.19 \%$, their number accounted for 2.69 and $4.48 \%$ respectively in the 2nd year, and the situation was even more vulnerable in the $3 \mathrm{rd}$ and 4 th year. There was a tendency to decrease in the loss of labor capacity of males, and a significant increase in the loss of labor capacity of females: 1.34 and $7.16 \%$ in the 3 rd year and 1.86 and $7.53 \%$ in the 4 th year (Fig. 1).

Further studies were aimed at examining students' health status, the dynamics of disease incidence over one academic year, and comparing the disease incidence of the students of two universities. The results of the study showed that 62.8 $\%$ of the students of ZSU and $82.2 \%$ of the students of PNU were healthy and belonged to the main medical group for health reasons and could fulfill the program requirements for physical education and take tests in physical training. At the same time, $35.5 \%$ of the students of ZSU and $17.8 \%$ of the ones of PNU had disabilities and belonged to a special medical group. Among them, $1.7 \%$ of the students of ZSU and $0.4 \%$ of the students of NPU had chronic diseases, disabilities and were exempt from sports.

The analysis of the students' examination showed that the reason for the high disease incidence is living in radiation-contaminated territories. Thus, $10.3 \%$ of the students of ZSU and $11.4 \%$ of the students of PNU lived in the contaminated territories, often consuming foods and water from the area. In addition, we identified a number of major nutritional deficiencies in both universities that also contributed to poor health. The large learning load, stressful situations, poor sanitary and living conditions also affected the health of students.

The study found that in the first year of study, the number of sick students increased by $19 \%$ at ZSU, and by only $4.8 \%$ at NPU, where they took a number of additional health-im- 
Table I. The analysis of pupils' attending physical education classes while studying at the school in senior year ( $\mathrm{n}=1208, \%)$

\begin{tabular}{|c|c|c|c|c|c|c|}
\hline \multirow{2}{*}{ Types of classes } & \multirow{2}{*}{ Place of residence } & \multirow{2}{*}{ Gender } & \multicolumn{4}{|c|}{ Number of classes per week } \\
\hline & & & 3 and more & 2 & 1 & 0 \\
\hline \multirow{4}{*}{ Scheduled classes } & \multirow{2}{*}{ rural area } & males & 8.6 & 79.9 & 10.1 & 1.4 \\
\hline & & females & 3.9 & 83.5 & 10.2 & 2.4 \\
\hline & \multirow{2}{*}{ city } & males & 5.8 & 86.5 & 7.7 & - \\
\hline & & females & 2.7 & 90.1 & 6.6 & 0.6 \\
\hline \multirow{4}{*}{$\begin{array}{l}\text { Extracurricular classes in } \\
\text { sections, sports schools, } \\
\text { clubs }\end{array}$} & \multirow{2}{*}{ rural area } & males & 13.0 & 10.2 & 5.1 & 71.7 \\
\hline & & females & 3.2 & 3.9 & 10.2 & 82.7 \\
\hline & \multirow{2}{*}{ city } & males & 33.6 & 13.5 & 5.8 & 47.1 \\
\hline & & females & 11.4 & 9.8 & 3.8 & 75.0 \\
\hline \multirow{4}{*}{ Independent classes } & \multirow{2}{*}{ rural area } & males & 20.3 & 15.9 & 13.1 & 50.7 \\
\hline & & females & 14.2 & 3.9 & 6.3 & 75.6 \\
\hline & \multirow{2}{*}{ city } & males & 18.7 & 11.6 & 14.2 & 55.5 \\
\hline & & females & 14.7 & 5.4 & 10.3 & 69.6 \\
\hline
\end{tabular}

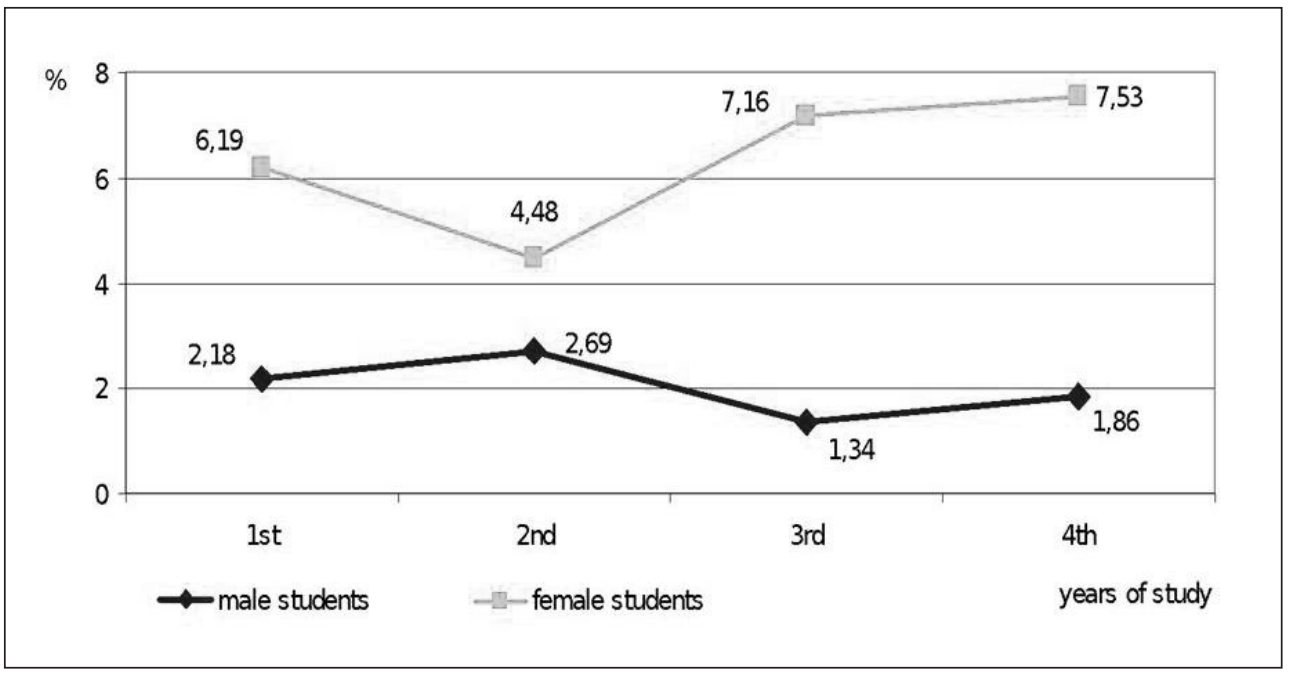

Fig. 1. The dynamics of the students loss of labor capacity due to illness during the calendar year (\% of the total number of days)

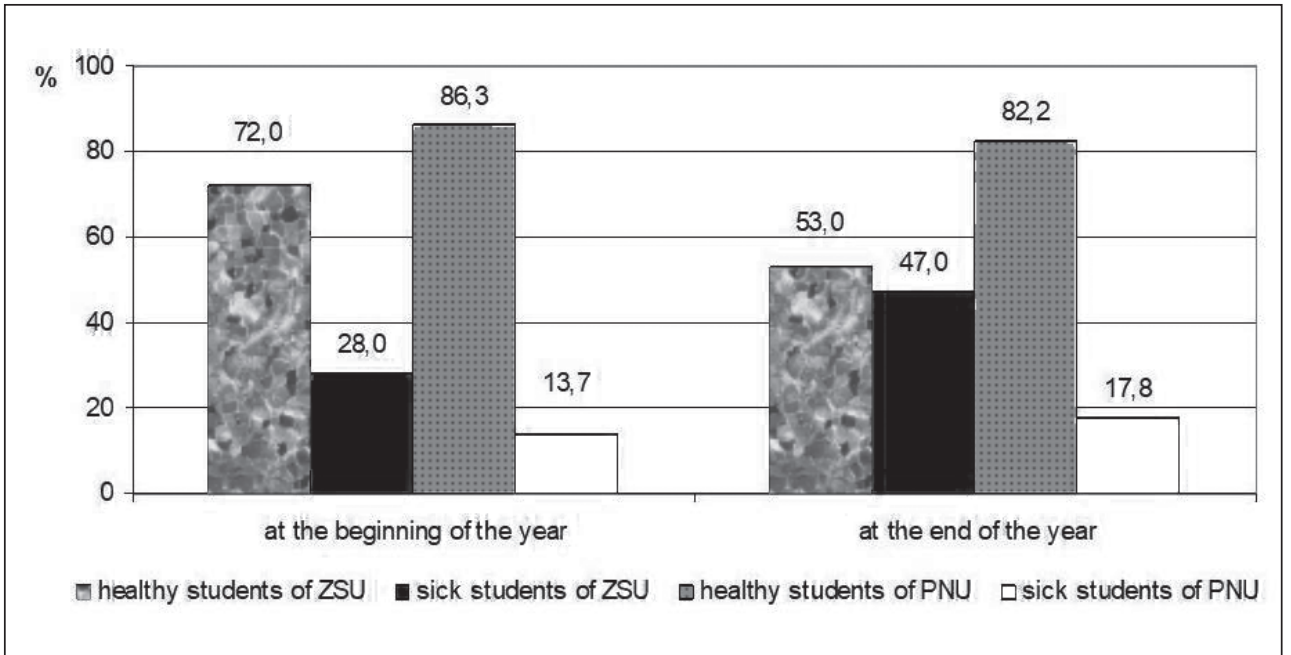

Fig. 2. The dynamics of the students' health during one academic year

proving measures in the process of physical education and extra-curricular time and provided additional free food for many students (Fig. 2).

The study of the students' health allowed us to determine the structure of the diseases $(n=648)$. Eye diseases associat- ed with visual deterioration (myopia of different degrees) predominate in the structure of diseases of the students of the 1 st -2 nd years $-28.5 \%$. Thyroid disorders took second place, including hyperplasia of the 1 st -2 nd degrees -18.2 $\%$, which can certainly be attributed to the consequences 
Table II. The self-assessment of health state by the students of different years of study ( $n=647, \%)$

\begin{tabular}{|c|c|c|c|c|c|c|}
\hline \multirow{2}{*}{ The state of health } & \multirow{2}{*}{ Gender } & \multicolumn{4}{|c|}{ The years of study } & \multirow{2}{*}{$\begin{array}{c}\text { Total } \\
\%\end{array}$} \\
\hline & & $1 \mathrm{st}$ & 2nd & 3rd & 4th & \\
\hline \multirow{3}{*}{ Perfect } & males & 5.7 & 9.4 & 8.6 & 2.9 & 6.7 \\
\hline & females & - & 3.1 & - & 8.2 & 3.2 \\
\hline & in total & 3.2 & 4.7 & 3.5 & 6.7 & 4.5 \\
\hline \multirow{3}{*}{ Good } & males & 60.0 & 67.1 & 57.1 & 50.0 & 60.1 \\
\hline & females & 46.3 & 51.4 & 41.2 & 51.8 & 49.1 \\
\hline & in total & 54.0 & 55.3 & 47.7 & 51.4 & 53.2 \\
\hline \multirow{3}{*}{ Satisfactory } & males & 30.5 & 21.9 & 17.1 & 32.4 & 26.5 \\
\hline & females & 46.3 & 37.2 & 45.1 & 31.8 & 38.9 \\
\hline & in total & 37.4 & 33.3 & 33.7 & 31.9 & 34.3 \\
\hline \multirow{3}{*}{ Poor } & males & 3.8 & 1.6 & 17.1 & 11.8 & 6.3 \\
\hline & females & 6.2 & 7.3 & 13.7 & 8.2 & 8.1 \\
\hline & in total & 4.9 & 5.9 & 15.1 & 9.2 & 7.4 \\
\hline \multirow{3}{*}{ Very poor } & males & - & - & - & 2.9 & 0.4 \\
\hline & females & 1.2 & 1.0 & - & - & 0.7 \\
\hline & in total & 0.5 & 0.8 & - & 0.8 & 0.6 \\
\hline
\end{tabular}

of radiation. Besides, $13.5 \%$ of the students were found to have disorders of the nervous system, $11.9 \%$ - cardiovascular diseases, $6.5 \%$ - diseases of the gastrointestinal tract. Some students were defined to have respiratory diseases (bronchial asthma, chronic bronchitis) - $3 \%$, scoliosis $2.2 \%$, vegetative-vascular dystonia in combination with thyroid hyperplasia - $2.9 \%$ and others. There were also cases of pancreatic diabetes, congenital anomaly of lower limbs, congenital deformity of eyes, etc.

The self-assessment of a health state by the students of NPU showed that only $6.7 \%$ of males and $3.2 \%$ of females indicated that they had a perfect state of health; 60.1 and $49.1 \%$ respectively - a good state; 26.5 and $38.9 \%$ - satisfactory; $6.3 \%$ and $8.1 \%$ - poor, and 0.4 and $0.7 \%$ - very poor (Table II). Females, the majority of who belonged to specialized medical group, had lower physical development and physical fitness, rated their health slightly lower.

The analysis of the results of self-assessment by the students from different educational departments indicated significant differences between the educational departments. The self-assessment confirmed that there were no students with perfect health in the special education department, the number of students with perfect health accounts for $4.8 \%$ of males and $4.5 \%$ of females in the main department, $15.3 \%$ of males and $1.5 \%$ of females in the sports department. There were also differences found in the self-assessment of the students with good, satisfactory and poor health (Table III). It should be noted that $6.2 \%$ of female students in the sports educational department confirmed a poor state of health despite engagement in sports. A very significant difference was also observed in the self-assessment of the students of the special education department concerning the poor and very poor health that proves the truth of such assessment.

The reduction of disease incidence and ensuring the efficient state of health of students is one of the priorities of the HEI physical education system. Therefore, it is necessary to create and maintain an environment that will contribute to the formation of goals, value orientations, principles of healthy lifestyles and control over the factors that determine or influence the students' health in the university. The students' value orientations influence their purposefulness, life activity or passivity. The developed system of value orientations of the students encourages them to take health-improving measures, to follow a healthy lifestyle. The analysis made it possible to establish that among a large number of students' value orientations, health value got the highest desirability status and occupied a dominant position. At the individual level, the value of health was determined by many factors, among which the objective health of an individual took the first place. The obtained data gave good reason to claim that the "dominant nucleus" in the structure of the students' life values were their own health, the health of their parents, love, family and children, material values, education (career), i.e. they were ranked 1 st -5 th. At the same time, other components of the value system, such as recognition by others, the environment protection, and the arts, occupied secondary places, that is, the last ones -15 th -17 th. Among the low ranked values were discipline, honesty, decency (males - 10, females 8 ), independence (10 and 12 respectively), faith in God and spirituality $(13,12)$, peace of mind (15 and 11). It is interesting to note that such leading activities for students as physical culture and sports took only 9th place for males and 14th place for females (Table IV).

The system of value orientations of students is not solid. A student lives and develops in the conditions of a certain social environment, living conditions, education and upbringing, the system of values is changed from year to year, new values appear, the old ones are rethought and re-evaluated. The students' state of health, level of physical development and physical fitness, that is, belonging to a certain educational department have impact on the hierarchy of life values of the student's personality. Such life values as one's own health; parents' health; love, family and children; material values are priorities and occupied the 
Table III. The self-assessment of health state by the students of different educational departments ( $n=647, \%)$

\begin{tabular}{|c|c|c|c|c|}
\hline \multirow{2}{*}{ The state of health } & \multirow{2}{*}{ Gender } & \multicolumn{3}{|c|}{ Education departments } \\
\hline & & Special & Main & Sports \\
\hline \multirow{3}{*}{ Perfect } & males & - & 4.8 & 15.3 \\
\hline & females & - & 4.5 & 1.5 \\
\hline & in total & - & 4.6 & 8.1 \\
\hline \multirow{3}{*}{ Good } & males & 41.6 & 69.0 & 59.3 \\
\hline & females & 35.0 & 54.6 & 50.8 \\
\hline & in total & 37.3 & 59.5 & 54.8 \\
\hline \multirow{3}{*}{ Satisfactory } & males & 35.6 & 23.0 & 25.4 \\
\hline & females & 51.6 & 33.2 & 41.5 \\
\hline & in total & 46.1 & 29.8 & 33.9 \\
\hline \multirow{3}{*}{ Poor } & males & 20.6 & 3.2 & - \\
\hline & females & 12.4 & 6.9 & 6.2 \\
\hline & in total & 15.3 & 5.6 & 3.2 \\
\hline \multirow{3}{*}{ Very poor } & males & 1.9 & - & - \\
\hline & females & 1.0 & 0.8 & - \\
\hline & in total & 1.3 & 0.5 & - \\
\hline
\end{tabular}

Table IV. The hierarchy of life values of the students of Zhytomyr region ( $n=648$, rank)

\begin{tabular}{|c|c|c|c|c|c|c|}
\hline \multirow{2}{*}{ Life values } & \multirow{2}{*}{ Gender } & \multicolumn{4}{|c|}{ The year of study } & \multirow{2}{*}{$\begin{array}{c}\text { Overall } \\
\text { rating }\end{array}$} \\
\hline & & $1 \mathrm{st}$ & 2nd & 3rd & 4th & \\
\hline \multirow{2}{*}{ Health } & males & 1 & 1 & 1 & 1 & 1 \\
\hline & females & 1 & 1 & 1 & 1 & 1 \\
\hline \multirow{2}{*}{ Parents' health } & males & 3 & 3 & 3 & 2 & 3 \\
\hline & females & 2 & 2 & 2 & 3 & 2 \\
\hline \multirow{2}{*}{ Love, family, children } & males & 2 & 2 & 4 & 3 & 2 \\
\hline & females & 3 & 3 & 3 & 2 & 3 \\
\hline \multirow{2}{*}{ Material values } & males & 4 & 4 & 2 & 4 & 4 \\
\hline & females & 5 & 4 & 5 & 4 & 4 \\
\hline \multirow{2}{*}{ Education (career) } & males & 5 & 5 & 7 & 6 & 5 \\
\hline & females & 4 & 5 & 4 & 5 & 5 \\
\hline \multirow{2}{*}{ Self-confidence } & males & 11 & 11 & 5 & 5 & 7 \\
\hline & females & 8 & 6 & 6 & 9 & 6 \\
\hline \multirow{2}{*}{ Working capacity } & males & 6 & 7 & 10 & 11 & 6 \\
\hline & females & 11 & 11 & 10 & 7 & 9 \\
\hline \multirow{2}{*}{ Intellectual development, erudition } & males & 9 & 8 & 6 & 8 & 8 \\
\hline & females & 6 & 7 & 7 & 6 & 7 \\
\hline \multirow{2}{*}{ Discipline, honesty, decency } & males & 12 & 9 & 14 & 12 & 10 \\
\hline & females & 7 & 10 & 8 & 8 & 8 \\
\hline \multirow{2}{*}{ Physical education and sports } & males & 8 & 6 & 11 & 13 & 9 \\
\hline & females & 10 & 14 & 14 & 15 & 14 \\
\hline \multirow{2}{*}{ Independence } & males & 16 & 12 & 8 & 9 & 12 \\
\hline & females & 9 & 9 & 12 & 11 & 10 \\
\hline \multirow{2}{*}{ Friends } & males & 13 & 10 & 13 & 10 & 11 \\
\hline & females & 14 & 12 & 11 & 13 & 13 \\
\hline \multirow{2}{*}{ Faith in God and spirituality } & males & 7 & 14 & 15 & 16 & 13 \\
\hline & females & 12 & 13 & 13 & 12 & 12 \\
\hline \multirow{2}{*}{ Peace of mind } & males & $14-15$ & 13 & 12 & 7 & 15 \\
\hline & females & 13 & 8 & 9 & 10 & 11 \\
\hline \multirow{2}{*}{ Recognition by others } & males & 10 & 16 & 9 & 14 & 14 \\
\hline & females & 15 & 15 & 15 & 14 & 15 \\
\hline \multirow{2}{*}{ Environment protection } & males & $14-15$ & 15 & 16 & 17 & 16 \\
\hline & females & 17 & 16 & 16 & 17 & 16 \\
\hline \multirow{2}{*}{ Art and culture } & males & 17 & 17 & 17 & 15 & 17 \\
\hline & females & 16 & 17 & 17 & 16 & 17 \\
\hline
\end{tabular}


same rating places - the 1st, $2 \mathrm{nd}, 3 \mathrm{rd}, 4$ th in all educational departments. At the same time, physical culture and sports took the 5th place in the values system of the male students of the sports department, and 12th - in the values system of females. In the special education department the physical education and sports was ranked only 12th for males and 15 th for females, in the main educational department - 8th and 14 th respectively.

\section{DISCUSSION}

Providing young people with broad freedoms is not enough for the development of physical culture. We need a socially-oriented cultural policy, scientific knowledge that could form the high aesthetic qualities and positive needs of young people, and help to acquire the necessary means for self-improvement and self-education. Socio-economic factors, environmental issues, the lack of health priority and motivation for a healthy lifestyle as a major factor in health formation, maintenance, preservation, and recovery play an important role. However, prioritizing health, students do not take care of it because there are many self-destructive health practices among young people (smoking, drug abuse, infectious diseases, alcohol abuse, gambling, Internet addiction, game addiction, etc.). It should also be noted that the student environment is unfavorable for the activation of the components of a healthy lifestyle; it promotes the spread of bad habits, the consequences of which students do not realize.

Most students do not have the need to take care of their health developed. Such students rely on their youth, the activities of medical institutions, the authority and professionalism of doctors, and neglect such effective and economically sound means as physical culture and sports. To improve students' health, it is important to engage them in classes of physical activity of person-centered choice during extracurricular activities and to provide the opportunity to continue scheduled physical activity with a sports orientation.

Forming students' health while studying at HEI involves the implementation of a number of areas, namely:

- ensuring real health by increasing the level of adaptive capacity of an organism, the ability to protect (or compensate) from the negative impact or use the positive impact of the factor on health maximally (the prevention of negative effects and the formation of positive ones);

- the creation of a favorable environment by reducing negative conditions or creating the conditions for the maximum realization of the positive properties of the factor (direct focus on health factors);

- ensuring conscious control of one's own health by promoting a healthy lifestyle and valeological education;

- the formation of a system of active health monitoring, which implies a systemic and systematic study of the psychological, physical and somatic components of health and the active use of the acquired information in the process of valeological education $[16,33]$.

The improvement of the health state and the level of phys- ical and functional preparedness of students by means of physical education is impossible without taking into account the relevant characteristics of an organism, and obtaining operational information about the students' state through medical and biological methods of research is connected with a number of difficulties. However, the solution to this problem can be facilitated by the results of subjective indicators, which, as a rule, reflect the state of a student's organism and do not require significant material and time costs [19].

The greatest effectiveness of health-improving training can be achieved by using basic methodical principles (gradual and continuous physical activity, the adequacy of physical activity to the level of health, the purposefulness of the means of health-promoting training, rhythmic use of various means), as well as the ratio of time spent on the development of physical qualities: $50-60 \%$ of the total time is dedicated to general endurance, $15-20 \%$ - the strength and strength endurance, up to $10 \%$ - the speed and speed endurance, 5-10 \% - the flexibility, 10-15\% - agility [33]. In addition, the authors set the limits of physical activity depending on the level of somatic health of students:

- for a low level: the intensity of classes is $40-50 \%$ of the maximum allowable heart rate; the means include walking, slow running, swimming, strength endurance and flexibility exercises; the frequency of applying in one lesson is 5-7 times per 10-30 minutes; the pace is steady, the priority method is repeated exercises;

- for a middle level: the intensity of classes is $56-66 \%$ of the maximum allowable heart rate; the means include fast walking, slow running, jumping, swimming, strength and speed endurance, agility exercises; the frequency of applying and volume in one session is 5-7 times per $15-40$ minutes; the pace is steady, the priority method is circuit training;

- for a high level: the intensity of classes is $70-80 \%$ of the maximum allowable heart rate; the means include exercises for the development of speed-power, power qualities, strength endurance, agility, jumping, swimming; the frequency of applying and volume in one session is 3-5 times per 10-50 min; the pace is steady and variable, the priority method is to perform the exercise to the last extremity.

We agree with the research of A. V. Maglovanyi [34] that the programmatic strategy of physical education should be based on a new paradigm of health, enriched with basic knowledge in the field of biology and physiology of health, physiology of sports, on establishing causative-consecutive relationships between ordinary physical activity, mental capacity and mental health taking into account psychological characteristics of a student's personality. The human body (physical status), one's mind and ability to think (intellectual component), moral and ethical principles (moral component), the ability to control emotions (emotional component), the ability to adapt to the conditions of life and work (a component of social status) are formed and developed. On the basis of the proposed conception, the author distinguishes the components of the health of 
a well-developed personality - physical, mental, social statuses; outlines the structure of the constituents of each, which teachers of HEI should take into consideration while working with students, namely the five hierarchically branched levels of health structure. The first level of health structure is integral individual health. The second level is health status, including physical, mental and social. The third level of health structure is formed by the components of statuses. The components of physical health are 1) internal physiological systems of an organism; 2) control systems of an organism. The constituents of mental health are 1) intelligence; 2) emotions; 3 ) character. The components of social health include 1) adaptation to physical conditions of life; 2) adaptation to working conditions; 3) adaptation to the moral and ethical standards of the environment. The fourth level is the integral components. Internal physiological systems of an organism are 1) physiological systems of the internal sphere (circulatory system, respiratory system, exchange systems); 2) control systems of the body (nervous and endocrine systems). The components of intelligence include 1) logical, associative, algorithmic, spatial thinking; 2) memory; 3 ) attention; 4) focus; 5) concentration, etc. The constituents of the emotional component embrace 1) mental experiences - the internal (impressive) mental constituent of emotions; 2) the display of emotions externally (motor and behavioral acts, facial expressions, speech) - the external (expressive) mental constituent of emotions. The constituents of the characterological component are the qualities of a person that are responsible for preserving and maintaining health (for example, optimism, purposefulness, etc.), that is, the system of character traits that determine the degree of self-organization and self-education of an individual. The integral components of adaptation to the physical conditions of life and social status include 1) the claims on the degree of comfort; 2) mobility; 3) physical abilities of adaptation to environmental conditions. The constituents of adaptation to working conditions embrace 1) adaptation to professional requirements; 2 ) adaptation to the intellectual surrounding of the professional environment; 3 ) the ability to overcome psychological barriers. The integral components of adaptation to the moral and ethical standards of the environment are 1) psychological compatibility with family environment; 2) communicativeness; 3 ) interpersonal relationships. The fifth level of health structure is formed by 1) the indicators of physiological systems of an organism, measured by laboratory or clinical diagnostic methods or obtained by calculations; 2 ) mental and social health indicators, determined by test and survey methods $[21,33,34]$.

The development of new scientifically sound ways of engaging students in physical education requires several methods to solve this problem, the main of which is the development of ways to increase students' physical activity, that is, engaging young students in independent exercises and sports in their spare time, combating bad habits, compliance with nutrition prescription and hygienically sound training regime, work and rest.
The other direction of improving the health of students is the inclusion in the programs of physical education the issues of environmental education that provide students with a system of knowledge about the negative and positive impact of environmental factors on human health, the rules of life in a polluted environment, taking into account the areas of radioactive contamination.

The primary objective of further research is to engage students in the personal-oriented choice of fitness technologies, the development of differentiated methods of physical education classes, the complexes of special physical exercises that will allow increasing motor activity, working capacity, to improve the functional state of an organism, and to preserve students' health while studying at HEI. At the same time, we should undertake extensive educational and explanatory work on:

- the concept of health and its components;

- teaching the methods of determining the physical state and assessing one's own health;

- drawing students' attention to the preservation of their own health as the highest value of life;

- fostering a sense of responsibility for one's own behavior and abandoning self-destructive youth health habits;

- teaching to acquire self-care skills;

- identifying and using the most important priorities of a healthy lifestyle as the factors for forming, preserving, strengthening, restoring and passing on health to the next generations;

- providing students with rational means and methods of physical education for the prevention of cardiovascular diseases, the diseases of the respiratory system, musculoskeletal system, metabolic disorders, etc.;

- the ability to define rational motor activity as a factor of improving one's own health and following it in practice; - the ability to properly use different types of becoming tempered (sunbathing, air baths, water procedures, winter swimming, walking barefoot, use of baths, etc.);

- the formation of a positive concept of active rest, providing knowledge, skills, and abilities to properly organize one's leisure and the leisure of close people;

- the ability to find one's social status, harmony with nature and one's own place in society.

Thus, the conducted research revealed the following tendency: 1) the deterioration of health state of Ukrainian students; 2) students are diverse for reasons of health; 3 ) the disease incidence rate of students from the same rural or urban area is dissimilar in different HEI; 4) there are differences in the health state of students from different regions; 5) targeted steps to preserve students' health and improve their lives have a positive tendency to reduce the disease incidence among youth. The results of our studies confirm the conclusions of many scientists $[1,2,5,8$ and others] and supplement them.

\section{CONCLUSIONS}

1. The basis of improving health and increasing the level of physical fitness of students is physical education, aimed at improving functional abilities of an organism, 
the development of physical qualities (strength, speed, endurance, flexibility, coordination), simultaneously improving special physical and technical readiness concerning the types of physical activity and acquisition of professionally-applied psychophysical skills and abilities, and in general, aimed at the improvement of health state.

2. The introduction of new forms and technologies of physical education of students, aimed at providing the foundation of health, requires the creation of a fundamentally new infrastructure of the national system of physical education of students. The theoretical, methodical and legal principles of designing this infrastructure and its further exploitation should be laid down in the national doctrine of physical education of the school and university students of Ukraine. The new forms and technologies of physical education of students are ultimately determined not only by the efficiency of using the methods, the availability of training bases, the material and technical support, the initial level of physical fitness and the state of health of students but by the whole complex of environmental, socio-economic, psychological and pedagogical, and sanitary and hygiene factors.

The prospects for further research are to explore the use of the means of health and fitness activities to improve the health of students.

\section{REFERENCES}

1. Kosiba G., Gacek M., Wojtowicz A., Majer M. Level of knowledge regarding health as well as health education and pro-health behaviours among students of physical education and other teaching specializations. Baltic Journal of Health and Physical Activity. 2019; 11(1): 83-95. doi: 10.29359/BJHPA.11.1.09

2. Gruzieva T., Galiienko L., Pelo I. et al. Health and lifestyle of students' youth: status, problems and ways of solution. Wiad Lek. 2018; 71(9): 1753-1758.

3. Prontenko K., Griban G., Prontenko V. et al. Health improvement of cadets from higher military educational institutions during kettlebell lifting activities. Journal of Physical Education and Sport. 2018; 18(1): 298-303. doi: 10.7752/jpes.2018.01040.

4. Bolotin A., Bakayev V. Structure and content of the educational technology of managing students' healthy lifestyle. Journal of Physical Education and Sport. 2015; 15(3): 362-364. doi:10.7752/ jpes.2015.03054.

5. Paffenbarger R. S., Olsen E. Zdorovyiy obraz zhizni [Healthy lifestyle]. Kyiv: Olympic Literature; 1999, 320 p. (In Russian).

6. Duboghaj 0. D., Aljoshyna A. I., Lavrynjuk V. Je. Osnovni ponjattja i terminy zdorov'jazberezhennja ta fizychnoji reabilitaciji v systemi osvity [Basic concepts and terms of healthcare and physical rehabilitation in the education system]. Lucjk:Volynsjkyj nacionaljnyj universytet imeni Lesi Ukrajinky; 2011, 296 p. (In Ukrainian).

7. Malimon 0., Volchinskiy A. Dinamika zahvoryuvanosti ta stanu zdorov'ya studentiv [Dynamics of student morbidity and health]. Fizichne vihovannya, sport i kultura zdorov'ya u suchasnomu suspilstvi. 2005; 1: 286-289. (In Ukrainian).

8. Apanasenko G., Dolzhenko L. Rivenj zdorov'ja i fiziologhichni rezervy orghanizmu. [The level of health and physiological reserves of the organism]. Teorija i metodyka fizychnogho vykhovannja i sportu. 2007; 1: 17-21. (In Ukrainian).
9. Kharchenko 0., Kharchenko N., Shaparenko I. et al. Analysis of the physical development of youth and the state of its health. Wiad Lek. 2019; 72(4): 575-578.

10. Warburton D., Nicol C. W., Bredin S. S. D. Health benefits of physical activity: the evidence. Canadian Medical Association Journal. 2006; 174: 801-809.

11. Prontenko K., Griban G., Dovgan N., et al. Students' health and its interrelation with physical fitness level. Sport Mont. 2019; 17(3): 41-46. doi 10.26773/smj.191018.

12. Bulych E. Gh., Muravov Y. V. Zdorovje cheloveka: Byologhycheskaja osnova zhyznedejateljnosty y dvyghateljnaja aktyvnostj v ee stymuljacyy [Human health: the biological basis of vital activity and motor activity in its stimulation]. Kyiv: Olympic Literature; 2002, 424 p. (In Russian).

13. Prontenko K., Griban G., Aloshyna A. et al. The physical development and functional state as the important components of the students' health. Wiad. Lek. 2019; 72 (12a): 2348-2353. doi: 10.36740/WLek201912115.

14. Budagh'janc Gh. M. Zdorovyj sposib zhyttja - osnovna umova profilaktyky deviantnoji povedinky pidlitka (istorychnyj aspekt) [Healthy lifestyle - the main condition for the prevention of adolescent deviant behavior (historical aspect)]. Pedaghoghika, psykhologhija ta medykobiologhichni problemy fizychnogho vykhovannja i sportu. 2010; 6: 25-28. (In Ukrainian).

15. Liakhova N. O., Holovanova I. A., Lysak V. P., et al. Shliakhy formuvannia zdorovoho sposobu zhyttia naselennia v praktytsi simeinoho likaria [Ways of promoting healthy lifestyles population in family doctor practice]. Suchasni medychni tekhnolohii. 2016; 2: 131—135.

16. Ghoncharenko M. S., Novykova V. Je. Valeologhichni aspekty formuvannja zdorov'ja u suchasnomu osvitjansjkomu procesi [Valeology aspects of the formation of health in the modern educational process]. Pedaghoghika, psykhologhija ta metodykobiologhichni problemy fizychnogho vykhovannja i sportu. 2010; 6:45-51. (In Ukrainian).

17. Mozolev 0., Bloshchynsky I., Alieksieiev 0. et al. Influence of modern fitness technologies on the state of health and development of motor abilities of 17-19-year-old female students. Journal of Physical Education and Sport. 2019; 19(Supplement issue 3): 917-924. doi:10.7752/jpes.2019.s3132.

18. Muntjan V. S. Analyz faktorov, opredeljajushhykh zdorovj'e cheloveka y okazyvajushhykh na negho vlyjanyja [Analysis of factors that determine human health and influence it]. Fyzycheskoe vospytanye studentov. 2010; 6: 44-47. (In Russian).

19. Gninyuk 0. Pedagogichniy kontrol za stanom zdorov'ya u sistemi fizichnogo vihovannya maybutnih inzheneriv informatsiynokomunikatsiynogo fahu [Pedagogical control of health state in the system of physical education of future engineers of information and communication profession]. Flzichna kultura, sport ta zdorov'ya natsiyi. 2006; 312-316. (In Ukrainian).

20. Kotov E. Dinamika fizichnoyi pidgotovlenosti studentiv [Dynamics of physical fitness of students. Physical education, sports and health culture in modern society]. Fizichne vihovannya, sport i kultura zdorov ya u suchasnomu suspilstvi. 2002; 1: 259-262. (In Ukrainian).

21. Griban G.P. Zhyttiediialnist ta rukhova aktyvnist studentiv [Life activity and mobility of students]. Zhytomyr: Ruta; 2009, 594 p. (In Ukrainian).

22. Futornyj S. M. Dvyghateljnaja aktyvnostj y ee vlyjanye na zdorovj'e y prodolzhyteljnostj zhyzny cheloveka [Motor activity and its effect on human health and longevity]. Fyzycheskoe vospytanye studentov. 2011; 4: 79-84. (In Russian). 
23. Semeniv B., Babych A., Bilenjkyj P. et al. Educational model of physical training of students of bio-technological profiles. Physical Education, Sports and Health Culture in Modern Society, 2018; 1(41): 52-60. doi:https://doi.org/10.29038/2220-7481-2018-01-52-60.

24. Prontenko K., Griban G., Bloshchynskyi I. Improvement of students' morpho-functional development and health in the process of sportoriented physical education. Wiad Lek. 2020; 73(1): 1753-1758. doi: 10.36740/WLek202001131.

25. Dolzhenko L. Fizichna pidgotovlenist studentiv z riznim rivnem somatichnogo zdorov'ya [Physical fitness of students with different levels of somatic health]. Moloda sportivna nauka Ukrayini. 2010; 9(4): 139-143. (In Ukrainian).

26. Stachon A., Pietraszewska J., Burdukiewicz A., Andrzejewska J. The differences in fat accumulation and distribution in female students according to their level of activity. Human Movement, 2016; 17(2): 87-93. doi: 10.1515/humo-2016-0009.

27. Zavydivska 0., Zavydivska N., Khanikiants 0. Self-management as a condition for creating a health culture among students. Journal of Physical Education and Sport. 2016; 16(1): 592-597. doi:10.7752/ jpes.2016.s1093.

28. Apanasenko G. L. Knygha o zdorovj'e [Health Book]. Kyev: Medknygha; 2007, 132 p. (In Russian).

29. Bodnar I. P., Stefanyshyn M. V., Petryshyn Y. V. Assessment of senior pupils' physical fitness considering physical condition indicators. Pedagogics, Psychology, Medical-biological Problems of Physical Training and Sports, 2016; 6: 9-17. doi:10.15561/18189172.2016.060 2.

30. Mozolev 0., Khmara M., Shorobura I. et al. Comparative analysis of the effectiveness of Polish and Ukrainian basic training programs in physical education for 9-10-year-old pupils. Universal Journal of Educational Research. 2019; 7(11): 2345-2351. doi: 10.13189/ujer.2019.071112.

31. Griban G., Prontenko K., Zhamardiy V. et al. Professional stages of a physical education teacher as determined using fitness technologies. Journal of Physical Education and Sport. 2018; 18(2): 565-569. doi:10.7752/jpes.2018.02082.

32. Prontenko K., Bloshchynskyi I., Griban, G. et al. Formation of readiness of future physical culture teachers for professional activity. Universal Journal of Educational Research. 2019; 7(9): 1860-1868. doi: 10.13189/ ujer.2019.070903.

33. Krutsevych T.Yu. Teoriia i metodyka fizychnoho vykhovannia [Theory and methods of physical education]: pidruchnyk dlia stud. vuziv fiz. vykhov. i sportu. T. 1.Zahalni osnovy teorii i metodyky fizychnoho vykhovannia. Kyiv: Olympic Literature; 2008, 391 p. (In Ukrainian).

34. Maglovanyi A. V. Osnovy informacijnogho polja zdorov'ja osobystosti [Basics of information field of personality health]. Visnyk Chernighivsjkogho nacionaljnogho pedaghoghichnogho universytetu imeni T. Gh. Shevchenka. Serija: Pedaghoghichni nauky. Fizychne vykhovannja ta sport. 2010; 81: 285-289. (In Ukrainian).
The work was carried out according to the plan of the Ministry of Agrarian Policy and Food of Ukraine on the theme of

"Theoretical and methodological bases of the optimization of the physical education system of the students of the Ukrainian higher educational institutions" (state registration number 0112U001618).

\section{ORCID and contributionship:}

Grygoriy P. Griban: 0000-0002-9049-1485 ${ }^{A, B}$

Natalia A. Lyakhova: 0000-0003-0503-9935 ${ }^{B}$

Oleksii V. Tymoshenko: 0000-0002-5310-4941 ${ }^{A, E}$

Zhanna G. Domin: 0000-0002-8315-6590 C

Nadya Yu. Dovgan: 0000-0002-4715-028X ${ }^{D}$

Mykola Z. Kruk: 0000-0003-4547-6515 ${ }^{B}$

Ivan V. Mychka: 0000-0001-9984-3451 ${ }^{F}$

Pavlo P. Tkachenko: 0000-0003-4407-8611 ${ }^{E}$

Bogdan S. Semeniv: 0000-0002-8302-1389 ${ }^{\mathrm{C}}$

Ganna P. Grokhova: 0000-0003-3562-1272 ${ }^{B}$

Natalya O. Zelenenko: 0000-0003-3777-1071

Kostiantyn V. Prontenko: 0000-0002-0588-8753 D

\section{Conflict of interest:}

Authors have no conflict of interests.

\section{CORRESPONDING AUTHOR Kostiantyn V. Prontenko}

Department of Physical Education, Special Physical Training and Sport, S. P. Koroliov Zhytomyr Military Institute, Zhytomyr, Ukraine tel: +380675069142

e-mail: prontenko-kostya@ukr.net

Received: 12.03 .2020

Accepted: 19.06 .2020

A - Work concept and design, B - Data collection and analysis, C - Responsibility for statistical analysis, D-Writing the article, $\mathbf{E}$-Critical review, $\mathbf{F}$ - Final approval of the article 